\title{
Effects of graded levels of Moringa oleifera leaf meal on growth performance of growing male New Zealand white rabbits
}

\author{
Egu, U.N. \\ Department of Veterinary Physiology and Pharmacology, Michael Okpara University of Agriculture, Umudike, Abia State, \\ Nigeria \\ Corresponding author: ucheegu1@gmail.com; +2348037792462
}

\begin{abstract}
A 60 day trial with sixteen growing male New Zealand White rabbits aged $3-4$ months and average weight of $1750 \pm 0.00 \mathrm{~g}$ were used to determine the effect of graded levels of Moringa oleifera leaf meal (MOLM) on growth performance. The rabbits were divided into 4 treatment groups represented as T1 (No MOLM, control), T2 (5\% MOLM), T3 (10\% MOLM), and T4 (15\% MOLM), replicated four times with a rabbit per replicate and randomly assigned to the treatment diets in a completely randomized design. The rabbits were fed in the morning and evening daily with compounded feed $(\mathrm{CP}=13.77-15.69 \%, \mathrm{ME}=$ $346.64-494.90 \mathrm{kcal} / \mathrm{g}$ ). Freshly cut forage consisting of Panicum maximum, Pennisetum purpureum and Centrosema pubescens were equally fed as basal diet. Water was provided ad libitum to the rabbits. In the end of the trial, data on growth performance were subjected to analysis of variance and statistical means separated with Duncan's New Multiple Range Test. The results showed no significant differences $(\mathrm{P}>0.05)$ among $\mathrm{T} 2$, T3, and $\mathrm{T} 4$ in average daily weight gain and feed conversion ratio, and no significant differences $(\mathrm{P}>0.05)$ among $\mathrm{T} 1, \mathrm{~T} 2$ and $\mathrm{T} 3$ in average daily feed intake. The results of the study further showed no mortality among the treatment groups. The results of this study indicated that New Zealand White rabbits could utilize Moringa oleifera leaf meal beyond the level of 15\% inclusion without any deleterious effects on their growth performance and thus further trial of MOLM inclusion is recommended.
\end{abstract}

Keywords: Growth, Moringa oleifera, performance, rabbits,

\section{INTRODUCTION}

Protein malnutrition is one of the major nutritional challenges in developing nations including Nigeria. The search for more economical source of animal protein makes rabbit production attractive (Egbo et al., 2001). The attributes promoting the production of rabbits include high fecundity, growth rate and the ability to utilize forages and turn out of low cost high quality proteins. This is because of their short gestation period, early sexual maturity, high prolificacy and ability to rebreed immediately after parturition, all leading to short generation interval (Biobaku \& Dosumo, 2003; Ani, 2006; Ogundele \& Apata, 2006; Safwat et al., 2014; Adeniji and Lawal, 2012).

The New Zealand white rabbit is an exotic breed that survives in tropical environment. It is a heavy breed that weighs about 4.1-4.5 kg at maturity (Egu, 2016). They have white fur that covers every part of the body with shiny eyes. They are commercial meat type and reach puberty at about 5 - 6 months of age ( Egu, 2016).

The rising prices of livestock feeds especially in Nigeria and the scarcity of conventional proteins and energy concentrates for the formulation of feeds have forced animal scientists to search for attractive, cheaper and readily available protein and energy sources. Green plants leaf ingredients with the crude protein content of fresh meal are used in the ration of the livestock to reduce cost of production, enhance reproductive performance, enhance health status and promote growth of farm animals, thus increasing overall livestock production when used as feed component or additive (Zendrato et al., 2019). One of such plant is Moringa oleifera. Moringa oleifera is one of the world's 
most useful plants for a variety of food and medicinal purposes in many countries in Africa, South East Asia, the Pacific and Carribean Islands and South America (Henuk, 2018). In recent time, the most prominent herbal products used in animal diet in Nigeria include Moringa oleifera leaf meal (Ologhobo et al., 2013). Moringa oleifera is used as a cheap protein supplement and as well improve digestibility of other diet components. Moringa oleifera leaf contains high crude protein (CP) $30.3 \%$ with $251 \mathrm{~kg}$ DM and negligible content of tannins and other anti-nutritive compounds (Gadzirayi et al., 2012; Abubakar et al., 2015; Egu, 2018).

The active constituents in the leaves of Moringa oleifera are glucosinolates such as 4 (alpha-L-rhamanosyloxy) benzyl glucosinolate which yield 4 (alpha-L-rhamanosyloxy) benzyl isocyanate following enzymatic degradation with myrosinase. Phenol carboxylic acid and fatty acid including oleic acid (60 to $70 \%)$, palmitic acid (3-12\%), stearic acid $(3-12 \%)$ as well as eicosanoic and lignoceric acids in addition to mustard oil and other constituents are also found in the leaves of Moringa oleifera (Egu, 2018). Moringa oleifera can replace the soya bean meal in the diet of the rabbits to $15 \%$ level of inclusion without any deleterious effects on the rabbits' performance. (Alemede et al., 2014). This study was carried out to determine the effects of graded levels of Moringa oleifera leaf meal on growth performance of growing male New Zealand White rabbits.

\section{MATERIALS AND METHODS}

The experiment was conducted at the Rabbitry unit of the Teaching and Research Farm of the Faculty of Agriculture, Abia State University, Umudike, Nigeria. This is within the South East Agro-ecological zone of Nigeria and lies within latitude $5^{0} 29^{\prime} \mathrm{N}$ and longitude $7^{0} 33^{\prime} \mathrm{E}$ and at an altitude of $122 \mathrm{~m}$ (400 feet) above sea level. The area has annual ambient temperature of $25-30{ }^{\circ} \mathrm{C}$, relative humidity between $65-80 \%$, and annual rainfall of $2000-2484 \mathrm{~mm}$. The soil is sandy loamy with average of pH 5.5 (Adiele et al., 2005).

\section{PROCEDURE FOR PROCESSING MORINGA LEAVES}

Moringa oleifera is native to India, Red sea and some part of Africa including Madagascar (Onu and Aniebo, 2011). Moringa is drought-tolerant and grows at a rainfall of 250$1500 \mathrm{~mm}$ per year (Martin, 2007). Fresh leaves of Moringa oleifera were harvested within Umudike near Umuahia, Abia State, Nigeria. The leaflets were stripped from the leaf petioles, washed in $1 \%$ saline solution for 3.5 minutes to remove dirt and microbes. The washed leaflets were drained using plastic buckets and spread on trays made with foodgrade mesh before drying. The leaves were dried under the shade by spreading them thinly on mesh tied on racks in order to retain most of the nutrients, green colour and the phyto-chemicals according to procedures suggested by Yang and Tsou (2006). The leaves were turned over once a day to improve the drying. The leaves were dried to $10 \%$ moisture content. Dried Moringa leaves were milled using a stainless steel harmer mill and sieved to $2 \mathrm{~mm}$ particle size. The dried leaf powder was packaged in dry plastic container and tagged Moringa oleifera leaf meal (MOLM). This was incorporated into the experimental diets during their formulation.

\section{EXPERIMENTAL ANIMALS, DIETS, DESIGN AND DURATION}

Sixteen growing male New Zealand White rabbits aged 3 - 4 months were used for this experiment. The rabbit were sourced from the National Root Crop Research Institute Umudike. Four experimental diets (Table 1) were formulated for the rabbits. MOLM was incorporated into the diets at $0.00 \%, 5.00 \%, 10.00 \%$ and $15.00 \%$ levels represented as $\mathrm{T}_{1}$, $\mathrm{T}_{2}, \mathrm{~T}_{3}$ and $\mathrm{T}_{4}$ respectively. The proximate compositions of the diets were analyzed using the analytical procedure as described by AOAC (2002). Four rabbits were allotted to the treatment groups in a Completely Randomized Design (CRD). A rabbit served as a replicate. Treatment one $\left(\mathrm{T}_{1}\right)$ which contained no MOLM served as the control. The study lasted for sixty (60) days.

Table I: Ingredient composition of experimental diets containing varying levels of Moringa oleifera leaf meal

\begin{tabular}{lcccc}
\hline & \multicolumn{4}{c}{ Dietary levels of leaf meal (\%) } \\
\cline { 2 - 5 } Ingredients & $\mathbf{T}_{\mathbf{1}}$ & $\mathbf{T}_{\mathbf{2}}$ & $\mathbf{T}_{\mathbf{3}}$ & $\mathbf{T}_{\mathbf{4}}$ \\
& $\mathbf{( 0 . 0 0 )}$ & $\mathbf{( 5 . 0 0 )}$ & $\mathbf{( 1 0 . 0 0 )}$ & $\mathbf{( 1 5 . 0 0 )}$ \\
\hline Maize & 47.00 & 47.00 & 47.000 & 47.00 \\
MOLM & 0.00 & 5.00 & 10.00 & 15.00 \\
Wheat offal & 15.00 & 10.00 & 5.00 & - \\
PKC & 14.00 & 14.00 & 14.00 & 14.00 \\
Soybean & 18.00 & 18.00 & 18.00 & 18.00 \\
Fish meal & 3.00 & 3.00 & 3.00 & 3.00 \\
Bone meal & 2.00 & 2.0 & 2.00 & 2.00 \\
Salt & 0.25 & 0.25 & 0.25 & 0.25 \\
Vita premix & 0.25 & 0.25 & 0.25 & 0.25 \\
Methionine & 0.25 & 0.25 & 0.25 & 0.25 \\
Lysine & 0.25 & 0.25 & 0.25 & 0.25 \\
\hline Total & $\mathbf{1 0 0}$ & $\mathbf{1 0 0}$ & $\mathbf{1 0 0}$ & $\mathbf{1 0 0}$ \\
& & & &
\end{tabular}


Table II: Proximate composition of experimental rabbit diets

\begin{tabular}{|c|c|c|c|c|}
\hline \multirow[b]{2}{*}{ Parameters } & \multicolumn{3}{|c|}{ Dietary level of leaf meal \% } & \multirow[b]{2}{*}{$\mathbf{T}_{4}(\mathbf{1 5 . 0})$} \\
\hline & $T_{1}(\mathbf{0 . 0})$ & $T_{2}(5.0)$ & $\mathbf{T}_{3}(\mathbf{1 0 . 0})$ & \\
\hline Protein & $13.77 \pm 0.10$ & $13.94 \pm 0.10$ & $15.11 \pm 0.10$ & $15.69 \pm 0.10$ \\
\hline Fat & $5.44 \pm 0.04$ & $5.70 \pm 0.04$ & $5.77 \pm 0.01$ & $5.81 \pm 0.02$ \\
\hline Fibre & $5.09 \pm 0.02$ & $4.60 \pm 0.35$ & $5.53 \pm 0.01$ & $5.70 \pm 0.04$ \\
\hline Ash & $4.71 \pm 0.01$ & $3.88 \pm 0.04$ & $3.97 \pm 0.01$ & $4.17 \pm 0.01$ \\
\hline Moisture & $10.33 \pm 0.02$ & $10.45 \pm 0.08$ & $10.36 \pm 0.02$ & $10.36 \pm 0.02$ \\
\hline Carbohydrate & $60.65 \pm 0.11$ & $61.43 \pm 0.15$ & $59.26 \pm 0.13$ & $58.27 \pm 0.13$ \\
\hline $\begin{array}{l}\text { Energy } \\
\text { (kcal/g) }\end{array}$ & $346.64 \pm 0.28$ & $352.78 \pm 0.16$ & $494.9 \pm 0.16$ & $481.00 \pm 0.11$ \\
\hline
\end{tabular}

Values show means of triplicate analysis \pm standard deviation.

Table IIIa: Proximate composition of fresh moringa leaf and shade dried moringa Leaf meal (as fed basis \%)

\begin{tabular}{lcc}
\hline Parameters & Fresh (FML) & Dried (DMLM) \\
\hline Protein & $3.79 \pm 0.10$ & $20.94 \pm 0.10$ \\
Fat & $1.35 \pm 0.01$ & $5.09 \pm 0.11$ \\
Fibre & $2.07 \pm 0.12$ & $8.15 \pm 0.03$ \\
Ash & $0.91 \pm 0.03$ & $6.18 \pm 0.04$ \\
Moisture & $70.41 \pm 0.03$ & $10.37 \pm 0.01$ \\
Carbohydrate & $21.46 \pm 0.14$ & $49.27 \pm 0.06$ \\
Energy (kcal/g) & $113.13 \pm 0.53$ & $326.48 \pm 0.68$ \\
\hline
\end{tabular}

Values show means of triplicate analysis \pm standard deviation.

$\mathrm{FML}=$ Fresh Moringa Leaf

DMLM= Dried Moringa Leaf Meal

Table IIIb: Chemical composition of forage (\% DM)

\begin{tabular}{lrrr}
\hline & PM & PP & \multicolumn{1}{c}{ CP } \\
\hline DRY MATTER & 85.30 & 73.69 & 71.91 \\
CRUDE PROTEIN & 9.79 & 7.87 & 7.97 \\
CRUDE FIBRE & 8.70 & 8.50 & 7.21 \\
ETHER EXTRACT & 1.20 & 2.59 & 2.31 \\
ASH & 8.10 & 8.51 & 8.14 \\
N-FREE EXTRACT & 57.43 & 67.24 & 62.54 \\
*ME (MJ/KGDM) & 1.46 & 1.20 & 1.10 \\
\hline
\end{tabular}

Calculated

$\mathrm{PM}=$ Panicum maximum

$\mathrm{PP}=$ Pennisetum purpureum

$\mathrm{CP}=$ Centrosema pubescens

\section{MANAGEMENT OF ANIMALS}

A 2-week pre-experimental period was allowed to enable the rabbits acclimatize. Each rabbit was housed in a single hutch of $50 \times 50 \mathrm{~cm}^{2}$ with wire mesh floor and wooden frames. Each hutch was tagged for easy identification of the rabbits. The house was naturally ventilated and the rabbits were reared in a clean environment. The necessary routine management practices were maintained. The rabbits were fed commercial concentrate diet (Grower Mash) $(\mathrm{CP}=16 \%$; $\mathrm{ME}$ $=2450 \mathrm{kcal} / \mathrm{kg}$ ) during 2 weeks of acclimatization. Freshly cut forage consisting of Pancium maximum, Pennisetum purpureum and Centrosema pubescens were fed as basal diet. The animals were fed two times daily (6am and $4 \mathrm{pm}$ ) using $700 \mathrm{~g}$ of each forage, and 2 kilograms of Grower Mash as supplement. Water was provided ad libitum to the rabbits. They were fed the experimental diets for 60 days, after which data collection and analysis were carried out.

\section{DATA COLLECTION}

\section{GROWTH PERFORMANCE}

Weight gain: At the commencement of the experiment after acclimatization, the rabbits were weighed using Electronic kitchen weighing scale, IndiaMART which weighs 1 gram7000grams and their initial average weights recorded. Thereafter, the rabbits were weighed every seven (7) days before feeding. The difference between the preceding and current week's weight was the weekly weight gain.

Feed intake: Daily feed intake was obtained using weigh back mechanism.

Feed conversion ratio $(\mathrm{FCR})$ : FCR $=$ Feed intake/Weight gain.

The legislative provisions on the care and use of animals were observed as approved by the Abia State University committee for research ethics.

\section{DATA ANALYSIS}

Data collected were subjected to one-way analyses of variance (ANOVA) using the technique of Steel \& Torrie (2006). Significant treatment means were separated using Duncan's New Multiple Range Test as described in Obi (2002).

\section{RESULTS}

The results of growth performance of grower male New Zealand white rabbits fed graded levels of Moringa oleifera leaf meal are shown in Table IV. There were no significant differences $(\mathrm{P}>0.05)$ among the treatment groups in initial body weight. However, there were significant differences 
Table IV: Growth performance of growing male new zeland white rabbits fed graded levels of Moringa oleifera leaf meal.

\begin{tabular}{rlllll}
\hline & \multicolumn{5}{c}{ Dietary level of leaf meal \% } \\
\cline { 2 - 5 } Parameters & T1 (0.0) & T2 (5.0) & T3 (10.5) & T4 (15.0) & SEM \\
\hline Initial body weight $(\mathrm{g})$ & 1750 & 1750 & 1750 & 1750 & 0.00 \\
Final body weight $(\mathrm{g})$ & $1780^{\mathrm{bc}}$ & $1810^{\mathrm{a}}$ & $1790^{\mathrm{b}}$ & $1800^{\mathrm{ab}}$ & 6.45 \\
Av. daily weight gain $(\mathrm{g})$ & $0.50^{\mathrm{b}}$ & $0.83^{\mathrm{a}}$ & $0.67^{\mathrm{ab}}$ & $0.83^{\mathrm{a}}$ & 0.08 \\
Av. total weight gain $(\mathrm{g})$ & $30.00^{\mathrm{bc}}$ & $60.00^{\mathrm{a}}$ & $40.00^{\mathrm{b}}$ & $50.00^{\mathrm{ab}}$ & 6.45 \\
Av. daily feed intake $(\mathrm{g})$ & $21.34^{\mathrm{ab}}$ & $22.34 \mathrm{a}$ & $20.39^{\mathrm{b}}$ & $20.75^{\mathrm{b}}$ & 0.43 \\
Av. Total feed intake $(\mathrm{g})$ & $1280.40^{\mathrm{ab}}$ & $1340.40 \mathrm{a}$ & $1223.40^{\mathrm{b}}$ & $1245.00^{\mathrm{b}}$ & 25.56 \\
Feed conversion ratio & $42.68^{\mathrm{a}}$ & $22.34^{\mathrm{b}}$ & $30.59^{\mathrm{ab}}$ & $24.90^{\mathrm{b}}$ & 4.53 \\
Mortality & 0.00 & 0.00 & 0.00 & 0.00 & \\
\hline
\end{tabular}

${ }^{\mathrm{abc}}$ : Means in the same row with different superscript are significantly $(\mathrm{P}<0.05)$ different. $\mathrm{SEM}=$ Standard error of mean .

$(\mathrm{P}<0.05)$ among the treatment groups in final body weight, average daily weight gain, average total weight gain, average daily feed intake, average total feed intake and feed conversion ratio.

Rabbits on $\mathrm{T}_{2}$ recorded the highest value of $1810 \mathrm{~g}$ in final body weight and this differed significantly $(\mathrm{P}<0.05)$ from rabbits on $\mathrm{T}_{1}$ and $\mathrm{T}_{3}$ which were similar $(\mathrm{P}>0.05)$ to each other in final body weight and also similar $(\mathrm{P}>0.05)$ to those on $\mathrm{T}_{4}$. There was no significant difference $(\mathrm{P}>0.05)$ between rabbits on $\mathrm{T}_{2}$ and $\mathrm{T}_{4}$ in final body weight. The lowest value in final body weight was observed in rabbits on $\mathrm{T}_{1}(1780 \mathrm{~g})$.

Rabbits on $\mathrm{T}_{2}$ and $\mathrm{T}_{4}$ recorded the highest value of $0.83 \mathrm{~g}$ in average daily weight gain and this differed significantly $(\mathrm{P}<0.05)$ from rabbits on control treatment $\left(\mathrm{T}_{1}\right)(0.50 \mathrm{~g})$ which were similar $(\mathrm{P}>0.05)$ to rabbits on $\mathrm{T}_{3}(0.67 \mathrm{~g})$ in average daily weight gain. There were no significant differences $(\mathrm{P}>0.05)$ among rabbits on $\mathrm{T}_{2}, \mathrm{~T}_{3}$ and $\mathrm{T}_{4}$ in average daily weight gain. The lowest value in average daily weight gain was observed in rabbits on control treatment $\left(\mathrm{T}_{1}\right)$.

Rabbits on $\mathrm{T}_{2}$ recorded the highest value of $60 \mathrm{~g}$ in average total weight gain and this differed significantly $(\mathrm{P}<0.05)$ from rabbits on $\mathrm{T}_{1}$ and $\mathrm{T}_{3}$ which were similar $(\mathrm{P}>0.05)$ to each other in average total weight gain. Rabbits on $\mathrm{T}_{3}$ were also similar $(\mathrm{P}>0.05)$ to those on $\mathrm{T}_{4}$ in average total weight gain. There was no significant difference $(\mathrm{P}<0.05)$ between rabbits on $T_{2}$ and $T_{4}$ in average total weight gain. The lowest value in average total weight gain was observed in rabbits on control treatment $\left(\mathrm{T}_{1}\right)(30 \mathrm{~g})$.

Rabbits on $\mathrm{T}_{2}$ recorded the highest value of $22.34 \mathrm{~g}$ in average daily feed intake which was similar $(\mathrm{P}>0.05)$ to rabbits on $\mathrm{T}_{1}$ but differed significantly $(\mathrm{P}<0.05)$ from rabbits on $\mathrm{T}_{3}$ and $\mathrm{T}_{4}$. The lowest value in average daily feed intake was observed in rabbits on $\mathrm{T}_{3}(20.39 \mathrm{~g})$.

Rabbits on $\mathrm{T}_{2}$ recorded the highest feed conversion ratio (general ability to convert feed to meat) of 20.83 which differed significantly $(\mathrm{P}<0.05)$ from rabbits on $\mathrm{T}_{1}(39.83)$ but were similar $(\mathrm{P}>0.05)$ to rabbits on $\mathrm{T}_{4}(23.26)$ and $\mathrm{T}_{3}$ (28.55). The lowest value in feed conversion ratio was observed in rabbits on $\mathrm{T}_{1}$.

\section{DISCUSSION}

The values for final body weight obtained in this study were higher than the range of 44.50 $64.25(\mathrm{~g})$ for final body weight reported by Iheukwumere (2004) for weaner rabbits fed with raw and boiled pigeon pea seed meal, and higher than the range of $1248.34-1376.60(\mathrm{~g})$ for final body weight reported by Iheukwumere et al. (2005) for grower rabbits fed with Microdesmis puberula leaf meal. This disparity in body weight could be attributed to age and nutritional status of these rabbits.

The lowest value in average daily weight gain observed in rabbits on control treatment $\left(T_{1}\right)$ could be attributed to decreased nutrients in the control group diet since $T_{1}$ contained no Moringa leaf meal. The values for average daily weight gain in this study were lower than range of 5.95 - $13.39 \mathrm{~g}$ in daily weight gain reported by Abubakar et al. (2015) for growing rabbits fed graded levels of Moringa oleifera leaf meal in diets. Similarly, the values for average daily weight gain obtained in this study were lower than the range of $10.31-11.80(\mathrm{~g})$ reported by Iheukwumere et al. (2005) for grower rabbits fed Microdesmis puberula leaf meal, and lower than the range of $18.87-22.35 \mathrm{~g}$ in daily body weight gain reported by Zendrato et al. (2019) for weaner rabbits fed dried Moringa oleifera leaf meal, and lower than the range of $16.71-21.90 \mathrm{~g}$ reported by Jiwuba and Ogbuewu (2019) for rabbits fed Moringa oleifera leaf meal supplemented diets. This may not be unconnected to differences in age, breed and nutritional status of the rabbits. The values for average total weight gain obtained in this study were higher than the range of $16.77-34.73 \mathrm{~g}$ reported by Iheukwumere (2004) in weaner rabbits fed raw and boiled pigeon pea seed meal, except rabbits on $\mathrm{T}_{1}$ whose average total weight gain was within the range. Similarly, the values for average total weight gain obtained in $T_{2}$ and $T_{4}$ were higher than the range of $20.75-45.10 \mathrm{~g}$ for average body weight gain reported by Iheukwumere et al. (2008) for 24 weeks old rabbits while the values obtained in $T_{1}(30 \mathrm{~g})$ and $\mathrm{T}_{3}(40 \mathrm{~g})$ were within the range. However, the values for average total weight gain in this study were lower than the range of $256.25 \mathrm{~g}-483.75 \mathrm{~g}$ in average total weight gain 
reported by Ufele et al. (2013) for rabbits fed Moringa oleifera (Drumstick tree), and lower than the range of 250.00 $-562.50 \mathrm{~g}$ in total weight gain reported by Abubakar et al. (2015) for growing rabbits fed graded levels of Moringa oleifera leaf meal in diets. The disparity in the values for average total weight gain obtained in this study could be attributed to genetic differences, age and nutritional status of the rabbits. The significant increase in body weights of rabbits fed Moringa oleifera leaf meal in this study compared to those on control diet may be linked to the excellent amino acid content of MOLM. The proteins of Moringa oleifera have very high biological value and essential amino acid (Mbajiorgu et al., 2011). Generally, the observed low growth rates in this study could be explained by the fact that the rabbits did not consume a lot of feeds to ensure higher growth. The rabbits must be fed to meet the energy requirement to sustain a rapid growth and development.

The values for average daily feed intake obtained in this study were lower than the range of 27.04-40.65g reported by Iheukwumere (2004) for weaner rabbits fed raw and boiled pigeon pea seed meal, and lower than the range of 73.10$79.81 \mathrm{~g}$ reported by Iheukwumere et al. (2005) for grower rabbits fed Microdesmis puberula leaf meal, and lower than the range of $30.05-56.35 \mathrm{~g}$ reported by Iheukwumere et al. (2008) for rabbit bucks. This disparity in average daily feed intake could be attributed to the crude fibre content of the various diets.

The highest average total feed intake observed in rabbits on $\mathrm{T}_{2}$ could be attributed to reduced crude fibre content of the diet which could have improved the palatability of the diet as $\mathrm{T}_{2}$ contained only 5\% Moringa oleifera leaf meal (Amaefule \& Obioha, 2001; Iheukwumere et al., 2008). Genetic differences might have also contributed to the higher feed intake in rabbits on $\mathrm{T}_{1}$ and $\mathrm{T}_{4}$ relative to $\mathrm{T}_{3}$.

The fact that rabbits on $\mathrm{T}_{2}(5 \%)$ Moringa oleifera leaf meal showed the best feed conversion ratio followed by $\mathrm{T}_{4}$ signified that Moringa oleifera leaf meal had the capacity of improving efficiency of feed utilization at these levels. This resulted in the highest average total weight gain observed in rabbits on $\mathrm{T}_{2}$ followed by $\mathrm{T}_{4}$. That no mortality was observed in all the treatments is an indication that Moringa oleifera leaf meal was not detrimental to the performance of the rabbits. Ayssiwede et al. (2011) found that MOLM inclusion in the diet up to $24 \%$ did not cause any adverse impact on the live body weight, average daily weight gain, feed conversion ratio and mortality in birds compared to their control.

\section{CONCLUSION}

The results of this study showed that Moringa oleifera leaf meal could affect growth performance of the growing New Zealand white rabbits: weight gain, feed intake and feed conversion ratio positively at the level beyond $15 \%$ inclusion. Hence, further trial of the spectrum of Moringa oleifera leaf meal inclusion level for growth performance in New Zealand White rabbits is desirable.

\section{REFERENCES}

Abubakar, M., Ibrahim, U., Yusuf, A.U., Muhammad, A.S. \& Adamu, N. (2015). Performance, Carcass and Organ Characteristics of Growing Rabbits Fed Graded Levels of Moringa oleifera Leaf Meal in Diets. Bayero Journal of Pure and Applied Sciences, 8 (2), 7-9.

Adeniji, A.A. and Lawal, M. (2012). Effects of Replacing Groundnut Cake with Moringa oleifera leaf Meal in the Diets of Grower Rabbits . International Journal of Molecular Veterinary Research, 2(3), 8-13

Adiele, J.G., Audu, H.O., Madu, T. \& Nwaogwugwu, R.O. (2005). Weather in 2005 at Umudike and its possible impact on root crops production in: National Root Crops Research Institute Annual Report for 2005 pp. 252-255.

Alemede, I.C., Onyeji, E.A., Tsado, D.N. \& Shiawoya, E.L. (2014). Reproductive Resources of Rabbits Does to Diets Containing Varying Levels of Horseradish (Moringa oleifera) Leaf Meal. Journal of Biological Agricultural. Healthcare, 4 (19), 62-68

Amaefule, K.U. \& Obioha, F.C. (2001). Performance and nutrient utilization of broiler starters fed diets containing raw, boiled and dehulled pigeon pea seeds (Cajanus cajan). Nigeria Journal of Animal Production, 28, 31-39.

Ani, A.O. (2006). Effect of toasted bambara (voandzeia subterranean, L) waste on haematology, carcass and organ characteristics of growing rabbtis. Proceedings $31^{\text {st }}$ Annual Conference of Nigerian Society for Animal Production Bayero University, Kano, Nigeria, March 21-25, 2006.

AOAC (2002). Official methods of Analysis. Association of office analytical chemists, Washington D.C., USA, $17^{\text {th }}$ edition.

Ayssiwede, S.B., Dieng, A., Bello, H., Chrysostome, C.A.A.M., Hane, M.B., Mankor, A., Dahouda, M., Houinato, M.R., Hornick, J.L. \& Missohou, A., (2011). Effect of Moringa oleifera (Lam) leaves meal incorporation in diets on growth performance, carcass characteristics and economic results of growing indigenous Senegal chickens. Parkistan journal of nutrition, 10 (2), 1132-1145.

Biobakun, W.O. \& Dosumo, E.O. (2003). Effects of supplementing a diet based maize and rice bran with 3 different improved forages on feed intake, digestibility and growth in rabbits. NSAP, 22, 179184.

Egbo, M.L., Doma, U.D. \& Lacdaks A.B. (2001). Characteristics of small-scale rabbit production and management in Bauchi metro-polis. Proceedings of the $26^{\text {th }}$ Annual Conference of Nigerian Society for Animal production (NSAP), 18-21 March 2001, ABU Zaria. Pp: 160-162. 
Egu, U.N. (2016). Effect of gonadotrophin (Diclair ${ }^{\circledR}$ ) on semen characteristics, body conformation and hormonal profile of mature male New Zealand White rabbits. International Journal of Agricultural Bioscience, 4(6), 260-265.

Egu, U.N. (2018). Effect of Gonadotrophin $\left(\right.$ Pergonal $\left.^{(\mathrm{R})}\right)$ on Semen Characteristics, Hormonal Profile and Biochemical Constituents of the Seminal Plasma of Mature West African Dwarf (WAD) bucks. Journal of Animal Science and Veterinary Medicine, 3(6), 200-210.

Gadzirayi, C.T., Masamba, B., Mupangwa, J.F. \& Washaya, S. (2012). Perforamcne of Broiler Chickens Fed on Mature Moringa oleifera Leaf Meal as a Protein Supplement to Soyabean Meal. International Journal of Poultry Science, 11 (1), 5-10.

Henuk, Y.L. (2018). Many Uses of Moringa (Moringa oleifera) in Human and Animal Nutrition. Journal of Agricultural and Allied Sciences, 7 (1), 42-46.

Iheukwumere, F.C. (2004). Performance, blood chemistry of weaner rabbits fed raw and boiled pigeon pea seed meal. Journal of Sustainable Tropical Agricultural Research, 12, 61-65.

Iheukwumere, F.C., Okoli, I.C., Anyanwu, G.A. \& Esonu, B.O. (2005). Growth performance, haematological and serum biochemical constituents of grower rabbits feed Microdemis puberula. Hook euphorbiaceae. Animal Production Research. Advances, 1, 24-31.

Iheukwumere, F.C., Onyekwere, M.U. \& Egu, U.N. (2008). Growth, Carcass and reproductive characteristics of male rabbits (bucks) fed raw and boiled pigeon pea seed meal (Cajanus cajan) meal. Pakistan Journal of Nutrition, 7 (1), 17-20.

Jiwuba, P.C. \& Ogbuewu, I.P. (2019). Potential of Moringa oleifera Leaf Meal to Replace Soybean Meal in Rabbits Diets and its Influence on Production Parameters. Asian Journal of Biological Sciences, 12(4), 656-663.

Martin, L.P. (2007). The Moringa tree Echo. North Fort Myers. FL 33917, USA. Available at http://www.echonet.org.

Mbajiorgu, C.A., Ngambi, J.W., Norris, D. \& Alabi, O.J. (2011). Effect of Dietary Lysine and Energy Ratio on Performance of Unsexed Indigenous Venda Chickens. Asian Journal of Animal and Veterinary. Advances, 6, 517-524.

Melesse, A., Tiruneh, W. \& Negesse, T. (2011). Effects of Feeding Moringa stenopetala Leaf Meal on Nutrient Intake and Growth Performance of Rhode Island Red Chicks under Tropical Climate. Tropical Subtropical Agroecosyst. 14, 485-492.
Obi, I.U. (2002). Statistical methods of detecting differences between treatment means $16^{\text {th }}$ ed. Enugu, Nigeria pp. 24-35.

Ogundele, O.O. \& Apata, D.F. (2006). Influence of Theobromide for dietary cocoa bean shell on Haematology and serum biochemical constituents of young rabtis. Proc. of Ann. Conf. NSAP, 12-15 ${ }^{\text {th }}$ March, Bayero University, Kano P.M. 3011 Kano.

Ologhobo, A.D., Adejumo, L.O. \& Akangbe, E.I. (2013). Comparison effect of Moringa oleifera leaf meal and oxytetracycline on hematology and serum biochemical profile of broiler finishers. International blood research and reviews 2 (1): 2936..

Onu, P.N. \& Aniebo, A.O. (2011). Influence of Moringa oleifera Leaf Meal on the apaerformance and Blood Chemistry of Starter broilers. Nigerian International Journal of Food, Agriculture and Veterinart Science. 1 (1): 38-44. 2011.

Safwat, M.A., Sarmiento-Franco, L. \& Santos-Ricalde, R.H. (2014). Rabbit Production Using Local Resources as Feedstuffs in the Tropics. Tropical Subtropical Agroecosystem, 17, 161-171.

Steel, R.G.D. \& Torrie, J.H. (2006). Principles and Procedure of Statistics. A Biometric Approach $3^{\text {rd }}$ Ed. Mc Graw-Hill book Co. Inc. New York.

Ufele, A.N., Ebenebe, C.L., Igwe, I.L., Mogbo, T.C., Akunne, E.C. and Aziagba, B.O. (2013). The Effects of Drumstick Tree (Moringa oleifera) Leaf Meal on the Average Weight Gain of Domestic Rabbits (Oryctolagus cuniculus). The Bioscientist, 1(1), 106-108.

Yang, R.Y. \& Tsou, S.C.S. (2006). Enhancing iron Bioavailability of vegetable through proper preparation principles and applications. Journal of international cooperation 1, 107-119.

Zendrato, D.P., Ginting, R., Warisman, Sirega, D.J.S., Putra, A., Sembiring, I., Hamdan, Ginting,J. \& Henuk, Y.L. (2019). Growth performance of weaner rabbits fed dried Moringa oleifera leaf meal. IOP Conference Series: Earth and Environmental Science, 260, 012058

Article history:

Received: July 2, 2021,

Revised: Sept 8, 2021

Accepted: Nov. 3, 2021 